\title{
AN EMPIRICAL STUDY ON FDI INFLOWS IN INDIAN IT AND ITES SECTOR
}

\author{
DIPA MITRA ${ }^{1}$, SHANTANU. P. CHAKRABORTY ${ }^{2}$ \& JAYJIT CHAKRABORTY ${ }^{2}$ \\ ${ }^{1}$ Associate Professor \& Coordinator, M. Phil. \& Ph. D. Programme, Indian Institute of Social Welfare and \\ Business Management, West Bengal, India \\ ${ }^{2}$ Full Time Lecturer, The Bhawanipur Education Society College, West Bengal, India
}

Indian Information Technology Sector is one of the largest software exporter all over the world and has put India in the Global Map. IT Industry had played a major role in transforming India image to a land of innovative entrepreneurs and a global player in providing world class technology solutions and business services. This has helped India to transform from an agriculture based economy to knowledge based.

The present study aims to identify the important components associated with FDI Inflows in Indian IT and IT Enabled Sector. It's an investigation from both qualitative as well as quantitative perspectives. Content analysis has been performed to recognize the significant factors of maximising FDI Inflows followed by Pearson Correlation and Regression Analysis along with Time Series Forecasting to understand the relation and impact in between dependent and independent variable and to forecast a trend line for all dependent and independent variables.

This nontrivial research lends a hand to the IT and ITES decision makers to strengthen their financial strategies in terms of maximising FDI Inflows. Present investigation may also be extended to any service or manufacturing industry inside or outside India to frame a global model to attract the extensive amount of FDI inflows and to reinforce financial policies, if necessary, in terms of Foreign Direct Investment.
\end{abstract}

KEYWORDS: IT, ITES, FDI, Inflows, Revenue, Export, Market \& GDP

Received: Sep 04, 2018; Accepted: Sep 25, 2018; Published: Oct 27, 2018; Paper Id.: IJISMRDDEC20182

\section{INTRODUCTION}

The expansion and integration of global financial capital markets has led to the changes in the composition of capital flows of the developing economies. In the era of globalization, FDI takes crucial part in the development of both developing and developed countries.

FDI has been associated with improved economic growth and development in the host countries, which has led to the emergence of global competition to attract FDI. It offers a number of benefits like overture of new technology, innovative products, emergence of new markets, opportunities of employment and introduction of new skills, which reflect on the growth of income of any nation.

The importance of FDI was recognized, right from where India attained its independence. But the major economic reforms took place in 1990s, when India adopted liberalization and globalization policies, after which the FDI inflows into India grew rapidly. The favourable policy regime of India and robust business environment has ensured that, foreign capital flows into the country continuously. The government has taken many initiatives right from liberalization in 1991 to the recent relaxing FDI norms across different sectors. India is a growing country, which has large space for consumer as well as capital goods. India's abundant and 
diversified natural resources, its sound economic policy, favourable market conditions and highly skilled human resources, make it a proper destination for foreign direct investments.

FDI to developing countries in the year 2000, was the leading source of outside financing and has become a key element of national progress for approximately all the countries in the world as a vehicle for technology stream and a significant source of non debt inflows for achieving spirited efficiency, by creating a trivial network of global interconnections. FDI provides an opening to host countries towards their economic enlargement, and opens up fresh prospects to home countries to obtain their earnings by employing the resources. India ranks $15^{\text {th }}$ in the service output, and provides employment to around $23 \%$ of the total workforce in the country. Various sectors under the service sector in India are hotels, transport, communication and storage, social and personal services, insurance, real estate and others.

There are various factors that influence the FDI inflows into a country. The investors consider and evaluate various aspects of a country, before investing in it. The relative importance of these determinants of FDI varies not only between countries, but also between different types of FDI. Traditionally, the determinants of FDI include the Size of the Market, Political Stability, Macro-Economic Environment, Legal and Regulatory Framework, and Access to Basic Inputs.

\section{LITERATURE REVIEW}

Narayanamurthy et al. (2010) examined the FDI inflows of BRICS countries for the period 1975 to 2007, except for Russia, for which the required data set was available from 1990 onwards. The results of the Panel Data Analysis revealed that Market Size, Labour Cost, Infrastructure, Currency Value and Gross Capital Formation are important determinants of FDI inflows of BRICS countries in terms of their potential. The Economic Stability and Growth prospects (measured by the inflation rate and industrial production respectively), Trade Openness (measured by the ratio of total trade to GDP) were found to be the insignificant determinants of FDI inflows of BRICS countries.

Hooda (2011)analysed the trends and patterns of the flow of FDI, and also the impact of FDI on the Indian economy, using time series data for the period 1991 to 2008. Trend Analysis, Annual Growth Rate, Compound Annual Growth Rate and Regression Analysis were the tools used for model building. It was observed from the results that, India continued to attract a substantial amount of FDI inflows due to its flexible investment regimes and policies, despite troubles in the world economy.

Hussaini (2011) highlighted the economic determinants of FDI inflow and sector wise trend in the Foreign Direct Investment (FDI) inflow into India using data from 1991 to 2009 for top ten sectors of Indian economy. It was concluded from the study that, the FDI inflow over the decades was very unsteady and fluctuating in various sectors of the Indian economy. FDI inflow was found to be highly correlated with the economic factors, considered in the study. The author suggested that India's interest to boost foreign investment by liberalizing rules on equity caps, investment reviews and other provisions, have impeded its ability to attract more foreign investment over the years.

Anitha (2012)analysed the FDI inflow into India during the post liberalization period, and projected the trends of FDI inflow into the country for a period of five years from 2010-11 to 2014-15 using Auto Regressive Integrated Moving Average (ARIMA) model. The various factors which influence the flow of FDI were examined, the causes for less inflow were identified, and remedial measures to increase the flow of FDI in India were suggested. The need to adopt innovative policies and good corporate governance practices at par with international standards, was identified as the key factor to attract more and more foreign capital in various sectors of the economy. 
Sahni (2012) examined the trends and the determinants of the FDI inflow into India from 1992-1993 to 2008-09, using Ordinary Least Square (OLS) method for the analysis of the time series data. GDP, Inflation and Trade Openness were found to be the important factors in attracting FDI inflows in India during the post reform period, whereas Foreign Exchange Reserves was not an important factor in explaining FDI inflows in India.

Goel et al. (2013) applied foreign direct investment model and economic growth model to study on the trends and patterns of FDI in India and its economic growth using Total Trade as a percentage of GDP, Foreign Exchange Reserves as a percentage of GDP, R\&D expenditure as a percentage of GDP, Ratio of external debts to export and Exchange rate for a period of 1991-2010. The results of Economic Growth Model and Foreign Direct Investment Model revealed that Trade GDP, Reserves GDP exhibit a positive relationship with FDI, while R\&D, GDP and Exchange Rate Variables exhibit a negative relationship with FDI inflows. Hence, Trade GDP and Reserves GDP variables are the pull factors for FDI inflows into the country, and R\&D, GDP and Exchange Rate are deterrent forces for FDI inflows into the country. The study also revealed that, FDI is a significant factor influencing the level of economic growth in India.

Sisili and Elango (2013) highlighted FDI and its competitiveness, and suggested that the basic determinants of the inflows of FDI are Size of the Market, Growth of the Market and the Exchange Rate of the country. The analysis indicated that, India's size of the market has expanded due to FDI inflow. The growth of the markets also increased at a significant level. But, the exchange rate has a negative influence on FDI inflow, because of the changes in the value of currencies.

Parashar (2015) investigated the determining factors of foreign direct investment (FDI) inflow in both China and India from 1980 to 2013, using econometric modelling. Linear Regression Analysis of time series data was done for 34 years. Macroeconomic indicators, such as market size, infrastructure, and opportunity cost to investors, trade openness, growth rate, policy changes and inflation were assumed to be the determinants. Both Ordinary Least Square Analysis and Partial Least Square Analysis approaches were applied to obtain regression results. The analysis revealed that, for both the countries, market size was an important factor. Also, in the case of China, lower wage rates played an important role in attracting FDI, while in India, it is the policy reforms that played a crucial role in attracting FDI.

Basu and Ghosh (2017) opined that, FDI inflow in India is extremely skewed across the major sectors of the economy, with the services sector accounting for more than half of the total FDI equity inflows. Having emerged as an attractive destination for FDI, the services sector contributes more than half of India's GVA, but its contribution to job creation has been less than proportionate to its contribution to GVA and also lacks in quality. The manufacturing sector on the other hand has not been able to generate employment adequately, owing to the capital-intensive mode of production, that has been adopted in this sector.

Sivakumar and Shalini (2018) expressed that, FDI is an apparatus for economic growth through its escalation of household capital, yield and employment. It also plays a fundamental role in the up sequence of technology, skills and administrative capabilities in various divisions of the economy. The authors also opined that, FDI has shown an incredible growth during 2000-10. Banking and Insurance, as well as Telecommunication sector picked up the maximum growth during this time period. FDI created high benefit jobs for skilled employees in the Indian service sector. 


\section{RESEARCH METHODOLOGY}

This empirical study aims to find out the most used words or parameters or factorsin terms of the impact of FDI with special reference to IT and ITES. In this regard qualitative analysis has been performed and on the basis of those words or factors, quantitative analysis is carried out.

Present study aspires to identify the relation and impact of those crucial words or factors and to forecast the trends for next few years.

Here Content analysis with the help of R- Programming is applied for the Qualitative research and Time Series Trend Analysis, Pearson Correlation and Regression Analysis are executed for the Quantitative part of research for which RBI Annual Reports and NASSCOM data sources are taken into consideration.

\section{ANALYSIS AND DISCUSSIONS}

\section{Qualitative Analysis}

The source file has been collected from a Govt site for public access, where Sector Specific Brief of Top Sectors Attracting FDI Inflows are plotted (on the basis of cumulative equity inflows between January, 2000 to December, 2016 of Sector Profile: Computer and Hardware.).

\section{Content Analysis: Both from Report and Dataset}

It is a content based analysis of the report using R Programming where a Word Cloud is generated. Here the most commonly occurring words are extracted from the document and their frequency is given in pie chart format.

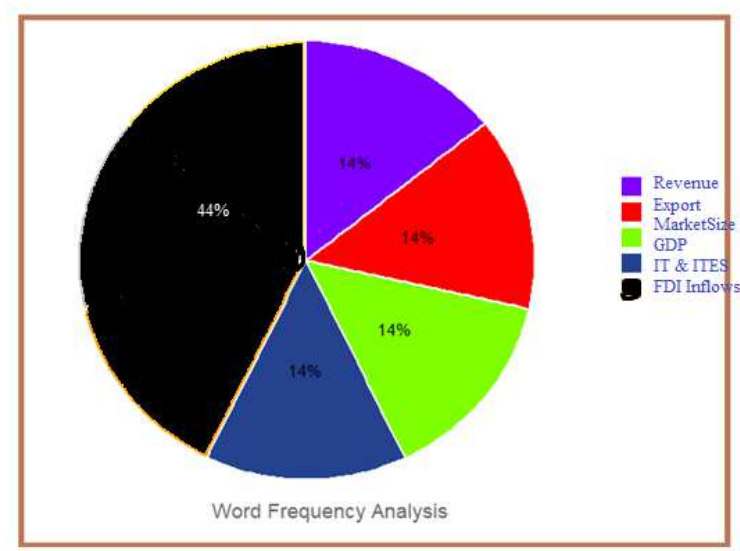

Figure 1

On comparing these most common words, it is found their occurrence is more or less the same in terms of their percentage of occurrence. The Images of the word cloud plot have been framed as a pie chart.

Again From the given CII-PwC datasets, the word cloud is formed. 


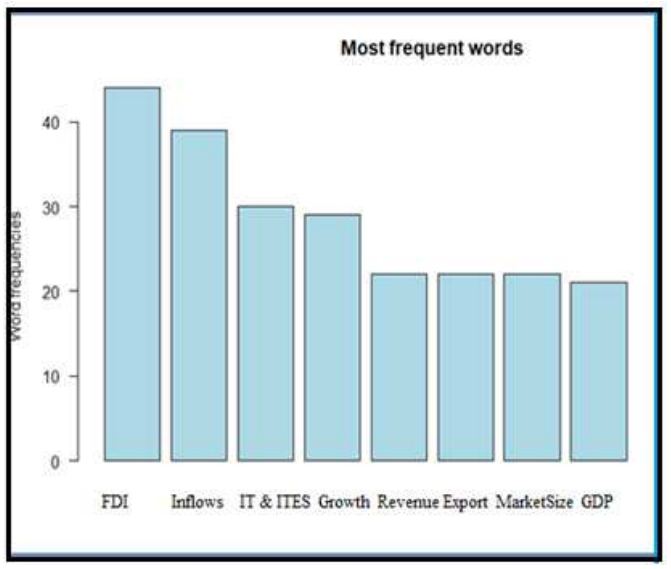

Figure 2

The most prominent words appeared in the diagram indicating the overall essence of -the reports. The most frequently occurring words was plotte on a bar graph and the result is shown above.

\section{Quantitative Analysis}

From the words or parameters depicted from Word frequency analysis are used for quantitative research. Secondary data have been collected on those significant words or parameters or factors. Accordingly, they are analysed.

\section{Time Series Forecasting}

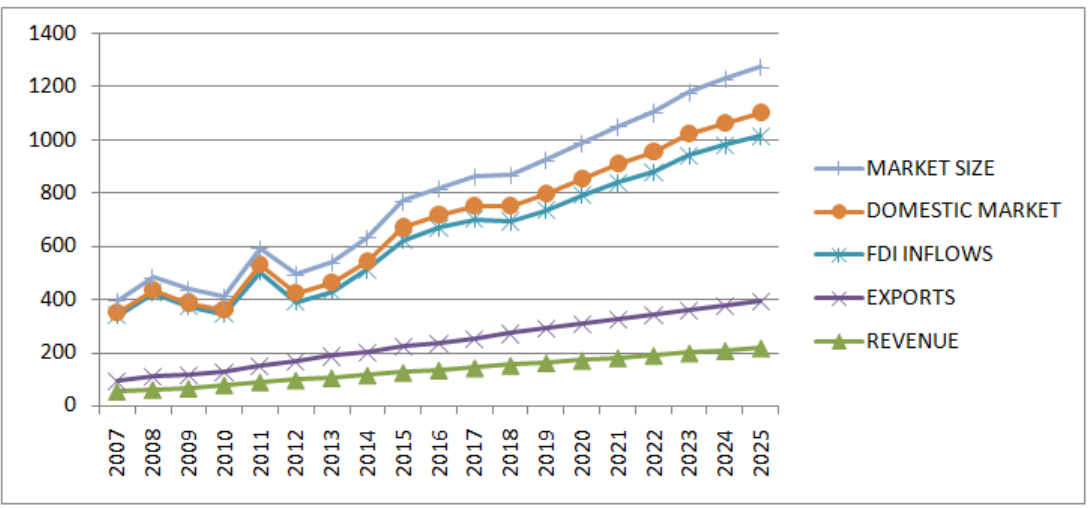

Figure 3: Time Series Forecasting Based on Author's Calculation

As per the graph portrayed above, it shows a positive trend for FDI Inflows, Market size, Exports and Revenue. According to the forecasting, the revenue earned for IT and ITES sector in the year 2007 was 52.1 US million Dollars that is estimated to move upward to 215.88 Us million dollars by the year 2025. Similarly the export that was 40.4 in US Dollar in year 2007 will move upward to 175.507 US million dollars by the end of the year 2025. Again the FDI Inflows which was 246 US million dollars in 2007 has been forecasted to move upward to 622.91 US million dollars by the end of the year 2025. The Market share of IT and ITES, which was 41 million US dollars in the year 2007 which seems to go up to 172.67 US million dollar according to the Time Series Forecasting. Moreover, the share of domestic market, which was 11.7 million US dollars in the year 2007 is estimated to go up to 87.94 US million dollars respectively. 
Interpretation of Pearson Correlation

Table 1

\begin{tabular}{|c|c|c|c|c|}
\hline \multicolumn{3}{|c|}{ Pearson Correlation } & $\begin{array}{l}\text { Correlation } \\
\text { Coefficients }\end{array}$ & Interpretation \\
\hline 1 & $\begin{array}{l}\text { FDI } \\
\text { inflows }\end{array}$ & Revenue & .707 & $\begin{array}{l}\text { It shows Positive correlation between FDI Inflows } \\
\text { and Revenue. As the correlation coefficient is. } 707 \\
\text { which is nearly equal to One }\end{array}$ \\
\hline 2 & $\begin{array}{l}\text { FDI } \\
\text { inflows }\end{array}$ & Exports & .777 & $\begin{array}{l}\text { It shows Positive correlation between FDI Inflows } \\
\text { and Exports. As the correlation coefficient is. } 777 \\
\text { which is close to One. }\end{array}$ \\
\hline 3 & $\begin{array}{l}\text { FDI } \\
\text { inflows }\end{array}$ & $\begin{array}{l}\text { Market } \\
\text { Size }\end{array}$ & .8 & $\begin{array}{l}\text { It shows Positive correlation between FDI Inflows } \\
\text { and Market Size. As the correlation coefficient is. } 8 \\
\text { which nearly equal to One }\end{array}$ \\
\hline 4 & $\begin{array}{l}\text { FDI } \\
\text { Inflows }\end{array}$ & GDP & -.312 & $\begin{array}{l}\text { It shows a negative correlation between FDI } \\
\text { Inflows and GDP. As the correlation coefficient is } \\
-.312 \text { which is less than one shows negative } \\
\text { correlation. }\end{array}$ \\
\hline
\end{tabular}

Interpretation of Regression Analysis

Table 2

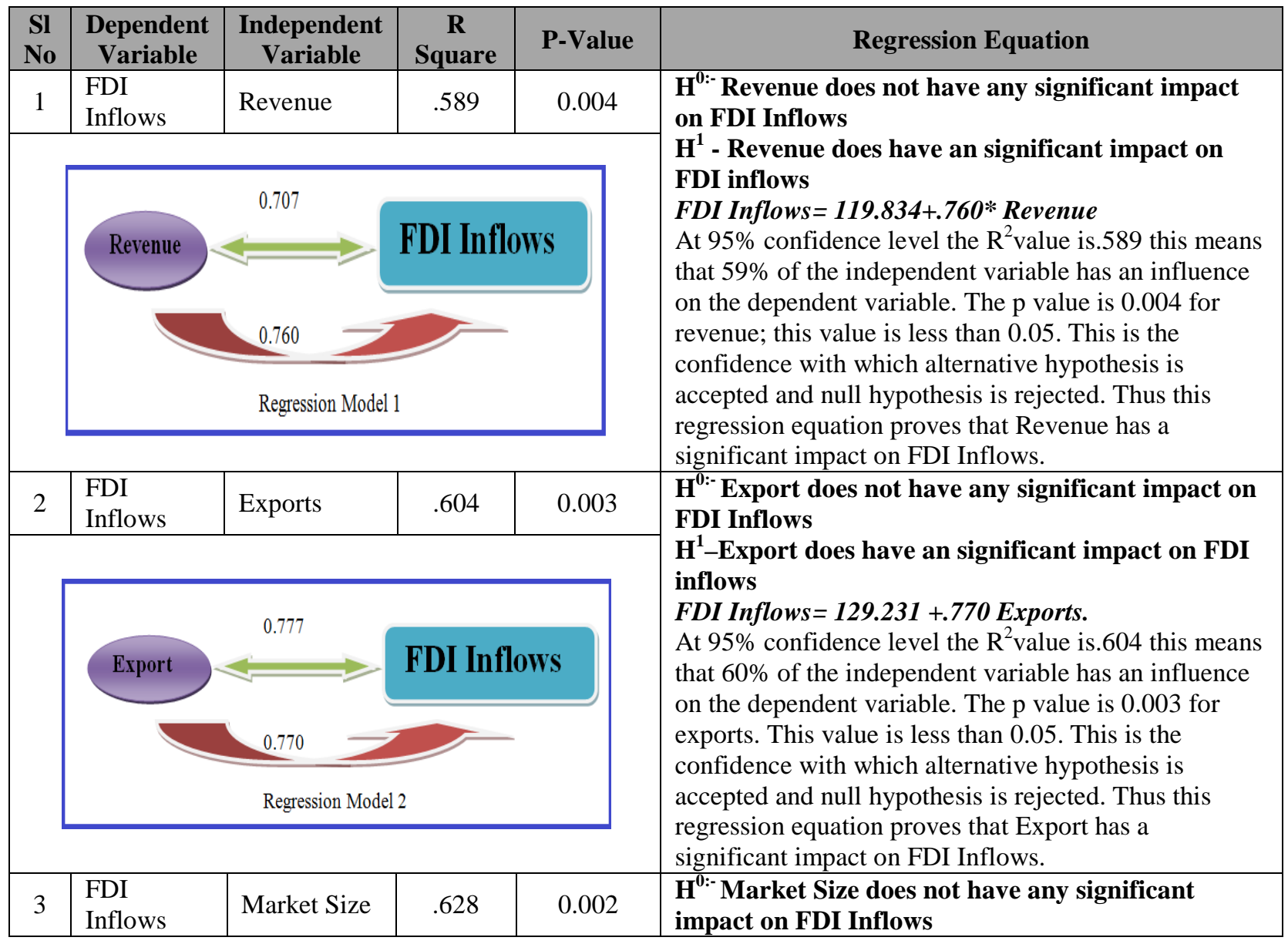




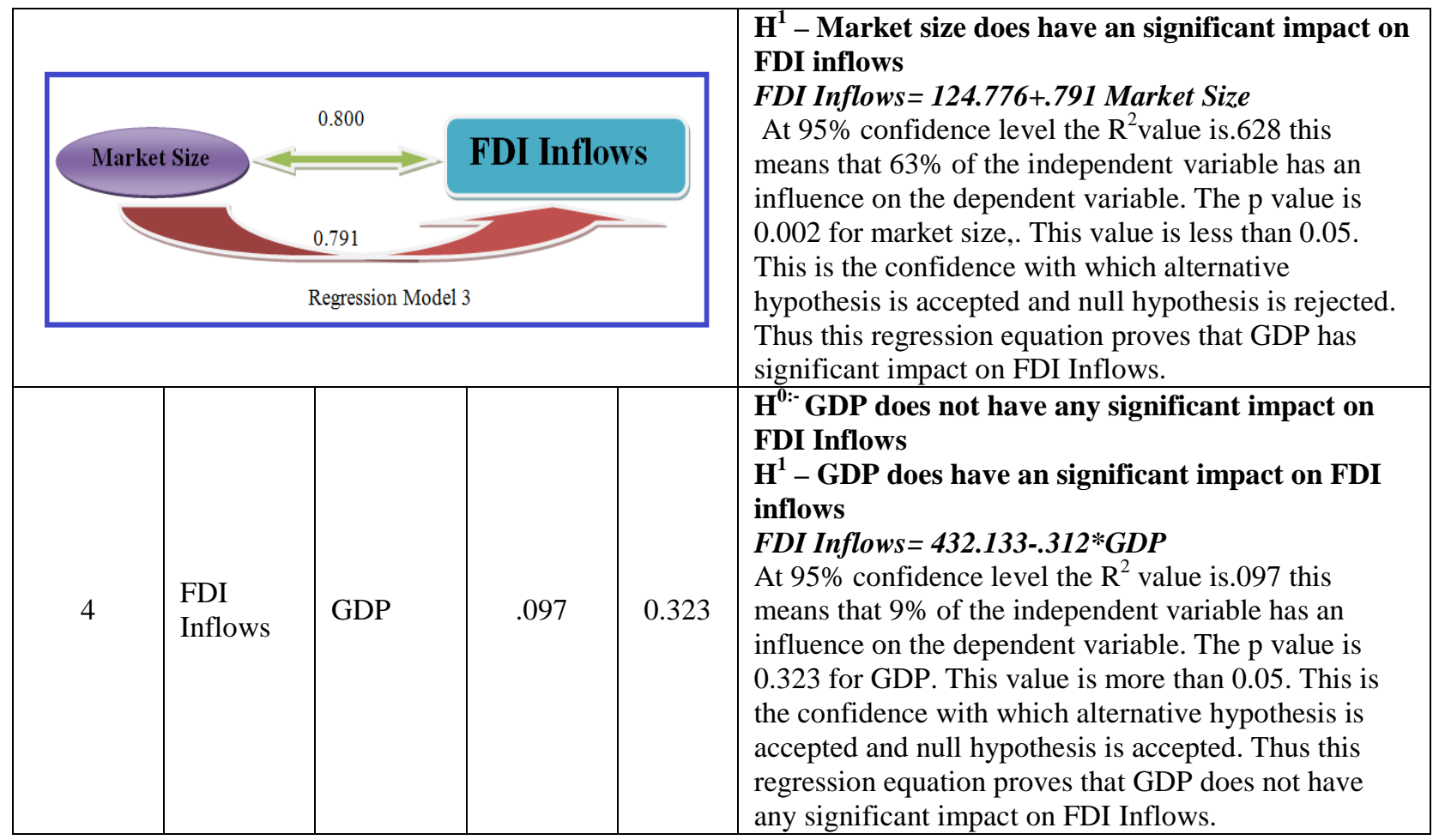

\section{CONCLUSIONS}

The above analysis shows the frequency of words based on textual analysis that is a qualitative analysis technique. The text that came in the picture has higher frequency compared to the other words in the text. Thus, the report emphasized on these particular words only. On comparing these most common words, it is found their occurrence is more or less the same in terms of their percentage of occurrence. The Images of the word Frequency Analysis have been framed as a pie chart. It gives the researcher an overall idea of the content of the reports that are available. Apart from this, since this report relates to FDI investments, word association levels with FDI as the reference word is also extracted. This leads to further research that facilitated to identify the relationship and impact amongst the most used words.

In this study word with highest frequency in most of the reports and data sources, FDI Inflows are considered as the dependent variable and other important words or parameters such as Revenue, Export Market Size and GDP are undertaken as independent variables.

The findings of Regression Analysis reveal that Revenue, Export and Market Size have significant impact on FDI inflows whereas GDP doesn't have any impact on it. Further Pearson Correlation Analysis shows a high positive correlation amongst the independent and dependent variables except GDP (has negative correlation with FDI inflows).

In the afore mentioned Regression Models, the coefficient of Correlation has shown with a light green double arrow and regression coefficients are marked by reddish curved arrow.

Further $\mathrm{R}^{2}$ value depicts that Revenue, Export and Market Size(individually) have 59\%, 60\% and 63\% impact on FDI inflows that means all independent variables have more or less similar amount of influence on the dependent variable. If in a given market condition Revenue and/or Export and/or Market Size are increased it will directly accelerate FDI inflows and Vice versa. 
This research is significant from the management perspective as it lends a hand to the IT and ITES players to strengthen their financial policy in terms of the causes and consequences of maximising FDI Inflows. There is enormous scope of this study as present investigation may also be extended to any service or manufacturing industry in our nation as well as across the Globe. From such extended research many more factors may also emerge that may vary from country to country or may be generalised as global standard parameters to attract a substantial amount of FDI inflows and to fortify the financial strategies in terms of Foreign Direct Investment.

\section{REFERENCES}

1. Narayanamurthy, V. K., Perumal, S. and Rao, K. C. S. (2010) "Determinants of FDI in BRICS Countries", International Journal of Business Science and Applied Management, 5(3).

2. Hooda, S. (2011) “A Study on FDI and Indian Economy”, Ph. D Thesis, National Institute of Technology, Kurukshetra.

3. Hussaini, N. H. (2011) “Economic Factors and Foreign Direct Investment in India: A Correlation Study”, Asian Journal of Management Research, 2(1).

4. Anitha, R. (2012) “Foreign Direct Investment and Economic Growth in India”, International Journal of Marketing, Financial Services and Management Research, 1(8), pp. 108-125.

5. Sahni, P. (2012) “Trends and Determinants of Foreign Direct Investment in India: An Empirical Investigation”, International Journal of Marketing and Technology, 2 (8).

6. Goel, S., Kumar, P. And Rao, S. (2013) "Trends and Patterns of FDI in India and its Economic Growth", Asian Journal of Multidimensional Research, 2 (3), pp. 6-22.

7. Ndubuisi, P., \& Uma, K. E. Government Policy And Foreign Direct Investment Inflows In Nigeria: An Empirical Exposition.

8. Sisili, T. And Elango, D. (2013) "FDI and its Determinants in India", International Journal of Scientific and Engineering Research, 4 (1).

9. Parashar, S. (2015) "Factors affecting FDI inflow in China and India”, University of Alberta.

10. Basu, S. and Ghosh, S. (2017) "FDI in India: Understanding the Implications for Growth and Job Creation", Journal of Management and Public Policy, 9 (1), pp. 5-16.

11. Sivakumar, V. and Shalini, S. (2018) "Foreign Direct Investment (FDI) in Indian Service Sector (A Study of Post Liberalization)”, Global Journal for Research Analysis, 7 (4). 